BASINDO : Jurnal Kajian Bahasa, Sastra Indonesia, dan Pembelajarannya

Volume 3 Nomor 1, 2019

Journal homepage : http://journal2.um.ac.id/index.php/basindo

\title{
PERAN GURU DALAM PEMBELAJARAN MENULIS PERMULAAN MENGHADI ABAD 21
}

\author{
Ima Hariyanti Ningsih, Retno Winarni, Roemintoyo* \\ Universitas Sebelas Maret, Universitas Sebelas Maret, Universitas Sebelas Maret
}

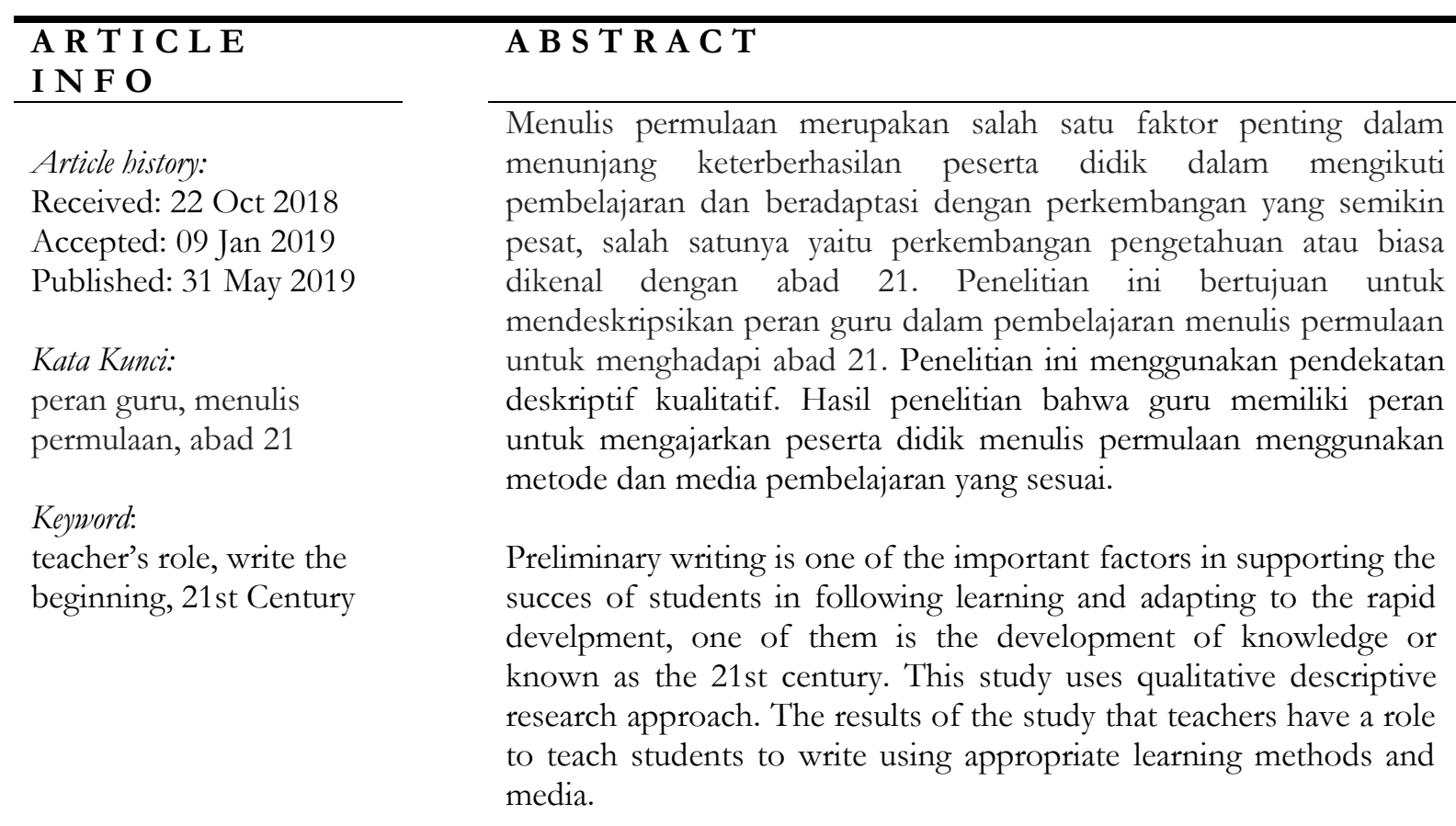

\section{PENDAHULUAN}

Perkembangan dunia pendidikan saat ini semakin berkembang pesat. Hal tersebut berdampak pula pada dunia pendidikan, salah satunya dalam pembelajaran bahasa Indonesia. Bahasa Indonesia memiliki fungsi sebagai alat komunikasi. Alat komunikasi terdiri komunikasi lisan dan komunikasi tulis. Komunikasi dapat dikuasai apabila seseorang memiliki keterampilan dalam berbahasa. Kemampuan berbahasa terdiri atas menyimak, berbicara, membaca dan menulis. Sadhono (2012: 3) menyatakan bahwa dalam penggunaan bahasa terdapat empat keterampilan dasar berbahasa yaitu menyimak, berbicara, membaca dan menulis. Pemerolehan keterampilan berbahasa, biasanya melalui suatu hubungan urutan yang teratur; mula-mula pada

\footnotetext{
* Corresponding author.

E-mail addresses: rymarhiyanti@gmail.com (Ima Hariyanti Ningsih), winarniuns@yahoo.com (Retno Winarni), roemintoyo@yahoo.co.id (Roemintoyo)
}

ISSN : 2579-3799 (Online) - BASINDO : Jurnal Kajian Bahasa, Sastra Indonesia, dan Pembelajarannya is licensed under Creative Commons Attribution-ShareAlike 4.0 International License (http://creativecommons.org/licenses/BY/4.0/). 
masa kecil belajar menyimak kemudian belajar berbicara, sesudahnya belajar membaca dan menulis. Keempat keterampilan tersebut pada dasarnya merupakan suatu kesatuan, merupakan catur tunggal. Kemampuan tersebut dapat diasah ketika mulai memasuki jenjang pendidikan. Salah satunya yaitu kemampuan menulis. Menurut Suparno dan M. Yunus (2003:3) menemukan bahwa menulis sebagai kegiatan penyampaian pesan (komunikasi) dengan menggunakan media bahasa tulis. Menerjemahkan bunyi menjadi lambang-lambang tulisan.

Kemampuan menulis pada kelas rendah (kelas satu) disebut dengan menulis permulaan. Menulis permulaan memiliki peranan penting untuk dikuasai oleh peserta didik, sebab menulis permulaan akan membantu peserta didik dalam berkomunikasi secara tulis (Andayani, Pratiwi, \& Priyatni, 2017). Menurut Rusyana (dalam Suhartini, 2015:160) bahwa menulis permulaan merupakan kemampuan menggunakan pola-pola bahasa secara tertulis untuk mengungkapkan suatu gagasan atau pesan. Pembelajaran menulis permulaan bersifat produktif. Menulis permulaan harus diperhatikan dengan baik utamanya di pendidikan dasar. Menurut Latae (2014:200) menulis permulaan merupakan bekal bagi peserta didik untuk mempelajari kompetensi dasar yang lain dalam mata pelajaran bahasa Indonesia dan mata pelajaran lain. Menulis permulaan membantu menunjang dalam menguasai pelajaran lain melalui tulisan.

Kemampuan menulis permulaan yang baik membantu peserta didik dalam menghadapi abad 21 yang menekankan bahwa harus berinovatif dan kreatif. Menurut (Rudi, 2011) tujuan pendidikan pada abad 21 adalah; 1) mempersiapkan orang dalam dunia pasang surut, dinamis, unpredictable, 2) perilaku yang kreatif, 3) membebaskan kecerdasan individu yang unik, serta 4) menghasilkan inovator. Peran guru dalam pembelajaran menulis permulaan sangat penting untuk menumbuhkan daya kreatif untuk peserta didiknya. Guru memerlukan metode atau teknik untuk membantu peserta didiknya agar mampu menulis dengan baik. Semakin berkembangnya teknologi dan pengetahuan, menulis akan menjadi sesuatu hal yang langka nantinya. Oleh karena itu, menulis menjadi suatu keterampilan dalam abad 21, sehingga akan menjadi sesuatu yang istimena dikemudian hari.

Berdasarkan hasil observasi dilapangan peneliti menemukan bahwa peserta didik belum menguasai menulis permulaan dengan baik, salah satunya disebabkan karena belum menghafal huruf dengan baik. Penelitian yang relevan yaitu penelitian yang dilakukan Azlia Latae, Sahruddin Barasandji, dan Muhsin tahun 2014 yang berjudul Upaya Meningkatkan Kemampuan Menulis Permulaan Siswa Melalui Metode SAS Siswa Kelas 1 SDN Tondo Kecamatan Bungku Barat Kabupaten Morowali. Keterbaruan dari penelitian ini adalah peran guru dalam pembelajaran menulis permulaan pada abad 21, sebagaimana diketahui bahwa abad 21 dikenal juga sebagai abad pengetahuan yang meminta untuk berinovatif dan kreatif serta memiliki keterampilan. Salah satunya yaitu keterampilan menulis yang membutuhkan daya kreativitas yang tinggi untuk menghasilkan suatu tulisan yang baik. Berdasarkan pemaparan tersebut maka tujuan penelitian ini adalah untuk mendeskripsikan peran guru dalam pembelajaran menulis permulaan untuk menghadapi abad 21.

\section{METODE}

Penelitian ini menggunakan pendekatan deskriptif kualitatif yang memiliki karakteristik alami sebagai sumber data langsung. Analisis data dalam penelitian kualitatif dilakukan sejak sebelum memasuki lapangan, selama di lapangan, dan setelah selesai di lapangan. Proses yang dimulai dengan menelaah seluruh data yang tersedia dari berbagai sumber yaitu melalui wawancara, observasi dan dokumentasi.

Data hasil penelitian ini berupa hasil wawancara dan dokumentasi. Suber data diperoleh dari key informan dengan snowball sampling. Subjek penelitian yaitu kepala sekolah dan guru kelas satu. Teknik pengumpulan data menggunakan observasi, wawancara, dan dokumentasi. Teknik analisis data Milles dan Huberman (2007: 15) yang terdiri atas: (1) pengumpulan data, (2) reduksi data, (3) mendisplai data, dan (4) penarikan kesimpulan atau verifikasi. Pada tahap reduksi data menunjuk pada proses pemilihan pemfokusan, penyederhanaan abstraksi data mentah yang 
diperoleh dari catatan-catatan lapangan yang tertulis. Reduksi data dapat terjadi secara kesinambungan. Reduksi data adalah pengumpulan data berproses, terdapat beberapa episode. Reduksi data membuat rangkuman, pengkodean, membuat tema-tema, membuat gugus-gugus, membuat pemisahan, dan membuat memo. Reduksi data merupakan proses terus-menerus setelah kerja lapangan hingga laporan akhir lengkap.

Penarikan kasimpulan atau verifikasi yaitu peneliti dapat mengambil kesimpulankesimpulan secara jelas, memelihara kejujuran, dan kecurigaan. Verifikasi harus disertai argumentasi yang panjang dan tinjauan di antara kolega untuk mengembangkan suatu temuan dalam rangkaian data lain. Makna penelitian kualitatif akan muncul dari data yang telah teruji kepercayaannya, kekuatannya, dan validitasnya.

\section{HASIL}

Peran guru sebagai seorang pendidik, orangtua, serata sebagai teman bagi peserta didiknya memintanya untuk selau mengikuti perkembangan. Peran guru dalam membantu peserta didiknya untuk mewujudkan keterampilan menulis sangat penting. Guru hendak mendampingi peserta didiknya dari mulai mengenal huruf, memahami huruf, menghafal, sampai mampu menuliskan huruf tersebut menjadi lambang-lambang tulisan.

Guru memiliki cara kusus untuk melatih peserta didiknya agar mampu menulis dengan baik. Proses pembelajaran guru kelas 1 SDN 01 Ketaon menggunakan media dan metode yang tepat, sehingga peserta didik dapat dengan mudah belajar menulis permulaan. Metode yang digunakan dalam pembelajaran menulis permulaan yaiu menggunakan metode SAS. Struktural Analitik Sintetik (SAS) merupakan salah satu metode yang dapat digunakan dalam pembelajaran menulis permulaan.

Peserta didik yang belum mahir menulis dan masih mengeja huruf dan membedakan huruf memerlukan perhatian kusus kedua setelah peserta didik yang belum menghafal huruf. Guru memulai melatih peserta didik membaca per-kata kemudian langsung dituangkan dalam bentuk tulisan. Guru SDN 01 Ketaon dalam menghadapi masalah ini menggunakan kartu huruf. Kartu huruf mempermudah peserta didik dalam belajar menulis permulaan. Melalui media kartu huruf peserta didik banyak yang mampu memahami huruf dan bentuknya, sehingga peserta didik lebih mudah merangkai suku kata, kata dan menjadi kalimat.

Terdapat tulisan naik turun atau belum bisa lurus dengan garis buku, sebab pada saat menulis dipapan tulis guru tidak menggunakan papan yang bergaris. Peserta didik kelas satu memiliki salah satu sifat yaitu meniru. Peserta didik akan meniru apa yang dituliskan oleh guru dan bagaimana bentuk tulisan tersebut. Guru harus berhati-hati dalam mengajarkan menulis permulaan. Guru kelas 01 SDN Ketaon mengatasi permasalahan tersebut dengan memberikan buku bergaris yang biasanya digunakan untuk menulis halus.

\section{PEMBAHASAN}

Abad 21 dikenal dengan masa pengetahuan. Pengetahuan yang semakin berkembang dan berbagai teknologi yang semakin canggih. Berkembangnya pengetahuan dan teknologi meminta seseorang untuk memiliki keterampilan lebih untuk mampu bersaing pada abad 21. Peran guru sebagai seorang pendidik, orangtua, serata sebagai teman bagi peserta didiknya memintanya untuk selau mengikuti perkembangan. Peran guru berdasarkan PP No. 19 Tahun 2017 guru adalah pendidik profesional dengan tugas utama mendidik, mengajar, membimbing, mengarahkan, melatih, menilai, dan mengevaluasi peserta didik pada pendidikan anak usia dini jalur pendidikan formal, pendidikan dasar, dan pendidikan menengah.

Guru abad 21 dituntut tidak hanya mampu mengajar dan mengelola kegiatan kelas dengan efektif, namun juga dituntut untuk mampu membangun hubungan yang efektif dengan siswa dan komunitas sekolah, menggunakan teknologi untuk mendukung peningkatan mutu pengajaran, serta melakukan refleksi dan perbaikan praktik pembelajarannya secara terus-menerus (Darling dalam Andriani, 2010:78). Semakin berkembangnya pengetahuan peran guru menjadi dominan 
dalam menumbuhkan, mengasah dan melatih peserta didiknya untuk membperoleh keterampilan yang hendak dikuasai peserta didik. Salah satu keterampilan yang harus dikuasai peserta didik yaitu keterampilan menulis permulan. Keterampilan menulis permulan termasuk keterampilan yang terdapat dalam abad 21 yang disebut dengan literasi.

Keterampilan abad 21 adalah (1) life and career skills, (2) learning and innovation skills, dan (3) Information media and technology skills; ketiga keterampilan tersebut dirangkum dalam sebuah skema yang disebut dengan pelangi keterampilan pengetahuan abad 21/21st century knowledge-skills rainbow (Trilling dan Fadel, 2009). Adapun konsep keterampilan abad 21 dan core subject 3R, dideskripsikan berikut ini. Gambar 1 menunjukkan skema pelangi keterampilan pengetahuan abad 21.

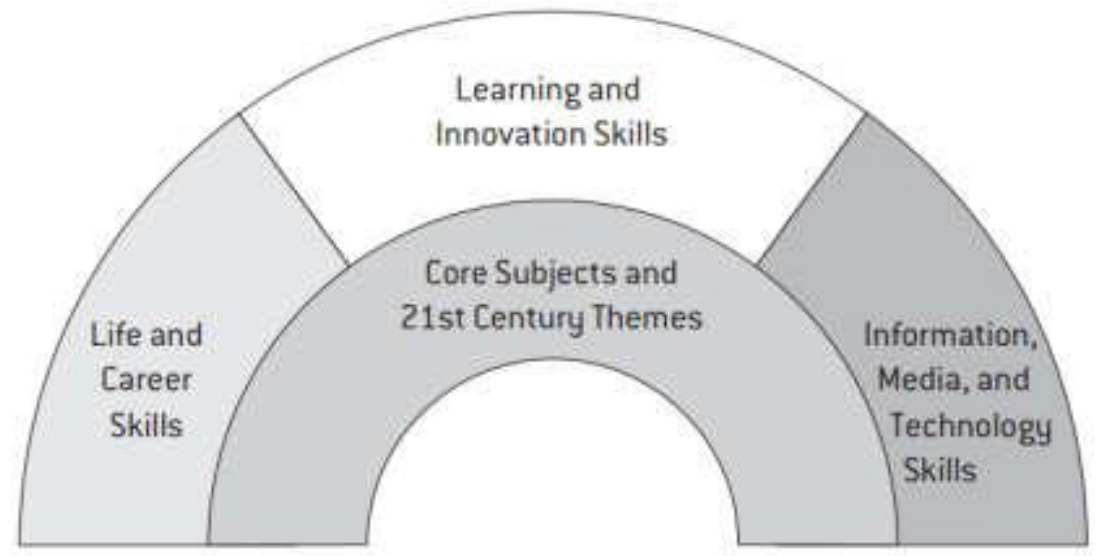

Gambar 4. Pelangi Keterampilan Pengetahuan Abad 21 Sumber: (Trilling and Fadel, 2009:47).

Pada skema yang dikembangkan oleh p21 diperjelas dengan tambahan core subject 3R. Istilah 3R dalam konteks pendidikan adalah singkatan dari reading, writing dan arithmatik, diambil lafal "R" yang kuat dari setiap kata. Dari subjek reading dan writing, muncul gagasan pendidikan modern yaitu literasi yang digunakan sebagai pembelajaran untuk memahami gagasan melalui media kata-kata. Dari subjek aritmatik muncul pendidikan modern yang berkaitan dengan angka yang artinya bisa memahami angka melalui matematika. Dalam pendidikan, tidak ada istilah tunggal yang relevan dengan literasi (literacy) dan angka (numeracy) yang dapat mengekspresikan kemampuan membuat sesuatu (wrighting). Jelas bahwa 3R yang diadaptasi dari abad 18 dan 19 tersebut, ekivalen dengan keterampilan fungsional literasi, numerasi dan ICT yang ditemukan pada sistem pendidikan modern saat ini.

Peran guru dalam membantu peserta didiknya untuk mewujudkan keterampilan menulis sangat penting. Guru hendak mendampingi peserta didiknya dari mulai mengenal huruf, memahami huruf, menghafal, sampai mampu menuliskan huruf tersebut menjadi lambanglambang tulisan. Guru yang kreatif akan menumbuhkan peserta didik yang kreatif pula. Peran guru di kelas 1 dalam mengajarkan menulis permulaan harus benar-benar berhati-hati, sebab pada kelas satu apa yang disampaikan guru akan tetap tertanam di dalam memori otak mereka.

Guru memiliki cara kusus untuk melatih peserta didiknya agar mampu menulis dengan baik. Proses pembelajaran guru kelas 1 SDN 01 Ketaon menggunakan media dan metode yang tepat, sehingga peserta didik dapat dengan mudah belajar menulis permulaan. Metode yang digunakan dalam pembelajaran menulis permulaan yaiu menggunakan metode SAS. Struktural Analitik Sintetik (SAS) merupakan salah satu metode yang dapat digunakan dalam pembelajaran menulis permulaan. Guru memanfaatkan rangsang gambar dan benda nyata untuk menggali bahasa peserta didik. Guru meminta menyalin tulisan yang berda digambar, hasil tulisannya dipisah menjadi suku kata dan diuraikan menjadi huruf. Penggunaan metode ini banyak peserta didik yang antusias dalam belajar, karena peserta didik merasa tidak jenuh. Penelitian relevan yang sesuai dengan metode ini yaitu penelitian yang dilakukan oleh Latae, dkk. (2014) penerapan metode SAS dapat meningkatkan kemampuan menulis siswa di kelas I SDN Tondo dibuktikan 
dengan pada siklus I mencapai 50,00\% dan ketuntasan belajar klasikal mencapai 33,33\%, siklus II daya serap klasikal mencapai 78,88\% dan ketuntasan belajar klasikal mencapai 100\%.

Peserta didik yang belum mahir menulis dan masih mengeja huruf dan membedakan huruf memerlukan perhatian kusus kedua setelah peserta didik yang belum menghafal huruf. Guru memulai melatih peserta didik membaca per-kata kemudian langsung dituangkan dalam bentuk tulisan. Guru SDN 01 ketaon dalam menghadapi masalah ini menggunakan kartu huruf. Kartu huruf mempermudah peserta didik dalam belajar menulis permulaan. Melalui media kartu huruf peserta didik banyak yang mampu memahami huruf dan bentuknya, sehingga peserta didik lebih mudah merangkai suku kata, kata dan menjadi kalimat. Hal tersebut sesuai dengan penelitian yang dilakukan Qodaroh (2017) bahwasannya penggunaan media kartu huruf menunjukkan hasil menulis permulaan yang meningkat dibandingkan dengan sebelum penggunaan media kartu huruf. Peningkatan itu terlihat dari hasil tes menulis permulaan antara siklus I dan siklus II. Pada siklus I diperoleh hasil rata-rata kelas sebesar 62,92 dalam kategori cukup. Setelah dilakukan tindakan pada siklus II diperoleh rata-rata kelas sebesar 82,13 dalam kategori baik atau mengalami peningkatan sebesar 18,75 atau 30,27\%.

Terdapat tulisan naik turun atau belum bisa lurus dengan garis buku, sebab pada saat menulis dipapan tulis guru tidak menggunakan papan yang bergaris. Peserta didik kelas satu memiliki salah satu sifat yaitu meniru. Peserta didik akan meniru apa yang dituliskan oleh guru dan bagaimana bentuk tulisan tersebut. Guru harus berhati-hati dalam mengajarkan menulis permulaan. Guru kelas 01 SDN Ketaon mengatasi permasalahan tersebut dengan memberikan buku bergaris yang biasanya digunakan untuk menulis halus.

\section{PENUTUP}

\section{Simpulan}

Berdasarkan pemaparan yang ditemukan dilapangan mengenai peran guru dalam pembelajaran menulis permulaan ditemukan untuk menumbuhkan keterampilan menulis permulaan peserta didik dan mampu menghadapi abad 21 berikut peran guru dalam pembelajaran. Guru memiliki cara khusus untuk melatih peserta didiknya agar mampu menulis dengan baik. Proses pembelajaran guru kelas 1 SDN 01 Ketaon menggunakan media dan metode yang tepat, sehingga peserta didik dapat dengan mudah belajar menulis permulaan. Metode yang digunakan dalam pembelajaran menulis permulaan yaiu menggunakan metode SAS.

Peserta didik yang belum mahir menulis dan masih mengeja huruf dan membedakan huruf memerlukan perhatian khusus kedua setelah peserta didik yang belum menghafal huruf. Guru memulai melatih peserta didik membaca perkata kemudian langsung dituangkan dalam bentuk tulisan. Guru SDN 01 ketaon dalam menghadapi masalah ini menggunakan kartu huruf. Guru memberikan buku bergaris yang biasa untuk menulis halus pada peserta didik yang hasil tulisannya belum bisa lurus, serta bagi peserta didik yang hasil tulisannya belum bisa membedakan tinggi rendah setiap huruf yang berbeda.

\section{Saran}

Berdasarkan hasil dan pembahasan penelitian yang telah dilakukan terdapat beberapa saran bagi peneliti selanjutnya untuk lebih meneliti guru untuk selalu memperhatikan kemampuan peserta didiknya dan keterampilan yang dimiliki oleh peserta didik. Mengetahui keterampilan peserta didik guru lebih mudah dalam mengarahkan peserta didiknya. Guru sebaiknya selalu menggunakan baik metode maupun media pembelajaran yang sesuai dengan pembelajaran agar menghadi peserta didik jenuh dalam belajar. Tidak lupa bahwa untuk selalu mengikuti perkembangan yang ada, sehingga dapat mempersiapkan peserta didiknya untuk menghadapi perkembangan tersebut.

\section{DAFTAR PUSTAKA}

Andayani, R., Pratiwi, Y., \& Priyatni, E. T. (2017). PENGEMBANGAN MODUL PEMBELAJARAN MENULIS CERPEN BERMUATAN MOTIVASI BERPRESTASI 
UNTUK SISWA KELAS XI SMA. BASINDO : Jurnal Kajian Bahasa, Sastra Indonesia, Dan Pembelajarannya, 1(1), 103-116. https://doi.org/10.17977/um007v1i12017p103

Milles, B. M dan Michael H. (2007). Analisis Data Kualitatif. Jakarta: UI Press.

Latae, A, dkk. (2014). Upaya Meningkatkan Kemampuan Menulis Permulaan Siswa Melalui Metode SAS Siswa Kelas 1 SDN Tondo Kecamatan Bungku Barat Kabupaten Morowali. Jurnal Kreatif Tadulako Online Vol. 2 No. 4 Hal. 199-213.

Peraturan Pemerintah Republik Indonesia Nomor 19 Tahun 2017 Tentang Perubahan Atas Peraturan Pemerintah Nomor 74 Tahun 2008 Tentang Guru.

Qodaroh. (2017). Peningkatan Ketrampilan Menullis Permulaan dengan Menggunakan Media Kartu Huruf pada Siswa Kelas I SD Negeri Gamer 02 Kota Pekalongan. Jurnal Cakrawala Pendas Vol. 3 No.2 Edisi Juli 2017. Hal. 72—81.

Rudy. (2011). Role ofst century teacher, http://rudy-unesa.blogspot.com/2011/02/peran-guruabad-xxi.html Retrieved 22 August, 2018.

Saddhono, K dan St. Y. Samet. (2012). Meningkatkan Keterampilan Berbahasa Indonesia Teori dan Aplikasi. Bandung: Karya Putra Darwati Bandung.

Suhartini, dkk. (2015). Peningkatan Kemampuan Siswa Membaca dan Menulis Permulaan Melalui Metode SAS di Kelas 1 SD Inpres Sibalaya Utara Kecamatan Tanambulava Kabupaten Sigi. Jurnal Kreatif Tadulako Online Vol. 5 No. 8 ISSN 2354-614X Hal.160-183.

Suparno dan Yunus. (2008). Keterampilan Dasar Menulis. Jakarta: Universitas Terbuka.

Trilling, B and Fadel, C. (2009).“21st Century Skills: Learning for Life in Our Times”, John Wiley \& Sons, 978-0-47-055362-6. 